\title{
Constitutional Fundamental Principles of National Idea Formation in Russia
}

\author{
Elena A. Pevtsova \\ Victoria G. Annenkova \\ Tamara V. Zametina \\ Russian University of Cooperation, 141014, Mytischi, Russia \\ Email: pevtsova@bk.ru
}

\section{Doi:10.5901/mjss.2015.v6n2s3p209}

\section{Abstract}

The purpose of the paper is the attempt that has been made to reveal conditions and constitutional fundamental principles of national idea formation in Russia, issues and youth policy implementation prospects on the basis of the analysis of the wide range of domestic and foreign sources. Careful consideration is also given to the co-relation of the definitions of "national idea" and "national (state) ideology" and the problems of the state national policy implementation in Russia. It is concluded that every stage of the constitutional development of post-Soviet Russia demonstrated its own state approaches to the solution of the federative and national problems. Federalism as a principle of the constitutional system affects nearly all the spheres of the public relations and also influences the structure and functioning of the government authorities. Ethnic policy is an integral part of the national policy. In addition, constitutional regulation focuses attention on the state policy under the conditions of the multinational state. Particular focus is placed upon the content of State National Policy Strategy of the Russian Federation. Its strengths and weaknesses are also examined.The paper makes out a case for establishing Ombudsmanship for Peoples' Rights in the Russian Federation. Special attention is paid to the role of youth in modernization of the public life.

Keywords: national idea, state national policy, Russian federalism, national (state) ideology, asymmetry of the constituent entities of the Federation, State National Policy Strategy, Ombudsman for Peoples' Rights, youth policy.

\section{Introduction}

\subsection{Urgency of the problem}

Globalization has been steadily growing in the world. It results in two divisive tendencies. It gives rise to integration of the states into the world community, unification of democratic institutions and processes, mechanisms of exercising state power and political collaboration, on the one hand, and to aspirations for maintaining regional, national, linguistic and confessional characteristics, on the other hand.

In the late 20th century the Soviet system fell apart . The new Constitution of the RF adopted on December 12, 1993 by national referendum laid the ground for creating a new Russian state. It raised a number of problems causing some controversy up to now.

The Russian public, which is at a tipping socio- historical point, is in instant need of the perfect knowledge of the purposes of economic and political changes as well as ideas that can weld a nation to fulfill them (Avakiyan, 1997). As a result, one of the priorities of development of the constitutional Russian democracy at the present development stage has been formation of the common Russian values and overall national idea. It is of key importance for Russia as a multinational and multiconfessional country.

As noted by the researchers, civilized parameters of the modern federalism, including the western one, are mostly set by framing supraconcept of the "post-national society"(Habermas,1996). The backbone central supraconcept in Russia, in one way or another, proves to be a "polyethnic state" (Dzapshba,1999).

\subsection{The results of the population perepesi}

According to the data of the 2010 All-Russian Population Census, formed on the basis of the self-determination of the citizens, the representatives of 193 ethnic nationalities are resident in the territory of Russia. Most of the peoples of Russia were formed for many centuries on the territory of the present Russian state and contributed to the development 
of the Russian art and statehood (Pevcova, Pravovoe vospitanie i formirovanie pravosoznanija v Rossii.Zhurnal Rossijskogo prava. 2003. № 10).

The multiethnic formation of the people is emphasized in the Preamble and Article 3 of the RF Constitution which states that the multinational people of the Russian Federation is the vehicle of sovereignty and the only source of power in the Russian Federation (Avakiyan, 1997).

It is necessary to develop a common national idea , common ideology in the unified state for harmonious wellbeing of the economic groups, political structures, social communities. The problem of its legal regulation for Russia is that , according to Article 13 of the Constitution, ideological plurality is recognized in the Russian Federation and no ideology may be instituted as a state-sponsored or mandatory ideology.

\section{Methodological Framewo}

\subsection{Leading opinion of Russian scientists}

The problem of formation of the national idea is considered in many works by domestic political scientists, the critical importance of the mentioned process (Alekseyev et al., 1996), the relationship between the national idea and the state (Khabibulin, Rakhomov, (1999)), the coherent state policy implementation in the sphere, its scientific support (Kovalenko \& Goloshumov, (1998)) being underlined .

However there is a lack of consensus of opinion on the content of the national idea in the literature. S.A Avakiyan points out a close connection between the Constitution and national ideology. The Constitution cannot help performing ideological, world-view functions as it "enshrines its own social values system" ( Avakiyan,(1997). The constitutional values," being the linchpin of the liberal-democratic ideology", are protected by the state ("Constitutional Law", 1996). In V.A. Chetvernin's opinion, declaring formal equality of ideologies in the framework of the priority of rights of a human being, the Constitution of the RF enshrines the rule of ideology with priority of human rights in the modern sense of the term ( Chetvernin, (1997)).

\subsection{About the content of the national idea}

There has also been a concept of "constitutional ideology" in the literature. As E.E.Barinov notes , " The state must promote transformation of the citizens' constitutional legal consciousness in a spirit of new constitutional ideology"(Barinov, (2001). It seems certain that this term is largely a scientific category. However, it is beyond argument that constitutional ideology must become the basis for the state ideology.

O.I.Tsybulevskaya states that spiritual vacuum in response to destruction of the values system as well as abandonment of the false idea of deideologization require development of the national legal doctrine (Tsybulevskaya, 2001).

As V.A. Tishkov noted, nurturing and cultivating a specific supranational ethnos of the Russian people, that is the Russian nationality, can become a platform for resilience support of the Russian state, maintenance of its unity, integrity and stability, achievement of the national consent (Tishkov, 1995).

It is worth noticing and supporting V.V.Mamonov who mentions that the foundation of the state ideology is supposed to be built up on the values that would be able to unite the Russian people," recall them to a sense of pride and respect to their Homeland, draw the representatives of different strata of the people together in the face of national security threat (Mamonov, 2002).

In the literature consideration is given to the necessity of making the concept of national idea in all the peoples residing on the territory of the Russian Federation not in their own right but "on the basis of the common historical and cultural background and common state language"(Markedonov, 2004) .

Moreover, the national idea is supposed to take into account a multiethnic aspect of the Russian state. The problems of national policy formation are reflected in the works by L.A.Morozova (1995), A.N.Kokotov (1999), V.A. Kryazhkov (2000), S.A. Avakiyan (2000), V.Y.Zorin, T.Y. Khabriyeva (2003) and others. Even so, the formation of the effective state national policy criteria remains relevant to this day.

The target of the research is a full range of public relations emerging during the process of formation and implementation of the national idea and national policy in Russia.

The scope of the research is the content of the constitutional legal regulation of the national idea, principles and fundamental objectives of the state national, youth policy and its implementation practice. 


\subsection{Methods for studying problems}

The scientific analysis is based on the method of dialectical materialism: conception of national idea and national policy as complex political legal phenomena, events in the aggregate of their internal and external relations. Other scientific methods such as historical, structural systemic, functional, comparative, technical and modeling ones contributed to acquiring of interdisciplinary knowledge about the subject.

The analysis of the mentioned problem in terms of structural and functional methods makes possible to draw a conclusion that national idea and national state policy are an integral attribute in the federal state system, reflect a certain type of interrelations as state policy elements, have an impact on the formation and implementation of the youth policy.

The technical approach through the theoretical analysis provides an insight into the content of the statutory acts regulating the state national policy, facilitates systematization of knowledge and realization of the findings of the research in the legal notions and categories, reveals defects and imperfections in the constitutional regulation of the national relations.

\section{Results}

Categorical analysis of the problems being investigated allows to draw a conclusion that the terms "national idea" and "national (state)ideology "are not identical. If a state is democratic, its national idea can be embodied in the state ideology and the latter can reflect its national idea. In case of the totalitarian regime, the ideology imposed by authorities might not express the will and interests of the people, be inconsistent with the national idea.

National idea affects spiritual foundation of the constitutional system of the country, is intended to integrate individual and collective interests of the people, territorial and religious communities. It is the constant that is able to provide stability in the dynamics of inconsistent social relations.

Yet, it should be taken into account that it is the Russian element of the unanimity, economy, culture and psychology that appears to be largely determinant for different ethnicities and the whole state. Though every ethnos has their own traditions they all are fellow-countrymen, representatives of the united multinational people of the country " united by a common fate on our land ", preserving "the historically established state unity" (The Preamble of the RF Constitution ).

While analyzing legal regulation in the sphere of federative relations from the date of adoption of the RF Constitution until today several stages can be distinguished and specific state approaches to solution of the federal and national questions during each of the following periods.

\subsection{Stages of solving the national question in Russia}

The first period (1993-1999) is a fledgling stage or a period of modern political and legal Russian federalism structuring. It was characterized by fuzziness of legal and regulatory distribution of joint competence matters between the federal centre and subjects of the Federation, ambiguity of financial and funding base of the corresponding competences, a lack of explicit legal regulation of the federative liability forms. As a result, consistency of common legal framework was violated, effectiveness of the performance of the state power federal bodies and bodies of state power of the subjects of the Federation was negated, living conditions worsened.

The second period (1999-2003)is a stage of consolidation of the power unity and Russia's executive vertical power structure. The problems of the prior period remained relevant. A number of bodies of state power of subjects of the Russian Federation unilaterally kept on taking steps violating consistency of common legal and economic framework of the country. The country's President initiated a number of Russian federalism consolidation measures such as legislative regulation of liability institution of the elected persons of the RF subjects for the actions infracting the Constitution; introduction of the institution of Presidential Plenipotentiary Envoy to the federal districts; development of the enforcement of the RF Constitutional Court's decisions mechanism concerning holding unconstitutional the regulatory enactments of the subjects of the Federation which contravene Federal law. During this period attention was also paid to the state national policy and problems of its implementation in the North Caucasus.

The enforcement of Art.72 of the RF Constitution put on the agenda an issue of separation of powers between the public bodies of the federal, regional and local levels. Consolidation of the executive vertical power structure and activities of the Presidential Plenipotentiary Envoys in the federal districts on the formation of the common legal framework resulted in the events when in 2002 the Russian Federation finally became a constitutional Federation recognizing the absolute priority of the RF Constitution in relation to the agreements for the division of subjects of authority and powers between 
the bodies of state power of the Russian Federation and bodies of state power of the subjects of the Russian Federation. Federal Law dated October 6,1999 "On General Principles of the Organization of the Legislative (Representative) and Executive Bodies of State Power of the Subjects of the Federation " was amended by alterations and additions with Federal Law dated June 4,2003. The issues which are related to the powers of the bodies of state power of the subjects of the Russian Federation on joint competence matters and administered by these agencies on an independent basis from the budget of the subject of the Federation were also defined by the latter. Moreover, a new procedure for making agreements for the division of subjects of authority and powers between the bodies of state power of the Russian Federation and bodies of state power of the subjects of the Russian Federation was established. It stipulates approval of agreements by federal laws.

The third period (since 2003 up to present) is a stage of centralization or federal centre dominance. This is a new period of federative relations development. By this time most of the subjects of the Federation had signed agreements for termination of the agreements for the division of subjects of authority and powers between the bodies of state power of the Russian Federation and bodies of state power of the subjects of the Russian Federation as they conflicted with provisions of the Constitution. Development and realization of the national projects conditioned the need for integration of the subjects around the federal Centre and distribution of the liability of the tiers of authorities in the sphere of social assistance. During this period a process of consolidation of the subjects of the Russian Federation has started.

Federalism as a principle of the constitutional system has a certain effect on the sphere of economic, political, ethno - cultural and other relations, influences the structure and functioning of the state power agencies at the federal, regional and local levels.

In view of multinationality of the country, national policy has always played a very important role. The significance of the national policy appeared to become apparent during the period of great social upheavals one of the most tragic of which is the Great Patriotic War (1941-1945). The utopian ideas of the Bolsheviks deprived fellow citizens of a sense of nation and Motherland, forced them to experience a reasonless pang of guilt for pre-revolutionary Russia that was thought to have been "a prison for the peoples". Just before the end of the war the authorities of the USSR ventured upon ideological revolution.

It is impossible to overstress the importance of the national idea during the period. As it was necessary to mobilize national and spiritual resources of the peoples of the USSR against the Nazi invaders, during the war under the conditions of the growing Soviet patriotism the national historical factor did strengthen. It was the period of the Great Patriotic War when the Soviet government smoothed relations with church and the clergy including alfaquis, dissolved Comintern, rejected "The Internationale" as a state hymn of the country. Strong emphasis was placed upon promotion of patriotism in the national republics of the USSR. Patriotic propaganda was realized in two ways: on the nation-wide and republican levels (Abdulatipov, 2000) .

Constitutional framework of the present state national policy of the Russian Federation were embodied not only in the Preamble to the Fundamental Law but in the first, second and third Chapters of the Constitution (P.3 Art.5, 9, P.2 Art.18,26, p.3 Art.68, Art.69,Cl."c" Art.71, CL. "b", "n" Art. 72 of the Constitution of the RF).

\section{Discussion}

Equality of the subjects of the Federation is one of the fundamental principles of federalism related to the constitutional provisions on the democratic aspect of the state power and legal state guarantying recognition, loyalty and protection of human rights and fundamental freedoms on the whole territory of the state.

Asymmetry certainly is not the evidence of inferiority of the federative model of the state structure. Its negative effects largely begin to appear only under the unstable conditions of the political system, during the period of aggravation of socio-economic problems, disruptiveness of informative and socio-cultural space. Limited in time political and legal transformations and search for the best model of the division of subjects of authority and powers between the bodies of state power of the Russian Federation, bodies of state power of the subjects of the Russian Federation and local selfgovernment make the asymmetric federation model unstable.

Unfortunately, experience has shown that the subjects of the Federation in their own constitutional and other legal acts successively stood up for their own statehood. For instance, the Constitution of most of the subjects of the Federation, that form parts of North Caucasian Federal District and the Volga Region Federal District, subsequent to the Federal Constitution (P.2 Art.5) make possible to include the definition "republic is a state within the Russian Federation" in their texts. Then in Art.1 of the Constitution of Republic of Tatarstan dated November 6, 1992 amended on November 222010 contrary to the legal views of the Constitutional Court of the RF there is a statement that says "sovereignty of Republic of Tatarstan is expressed in the possession of full state power outside the limits of authority of the Russian 
Federation and the powers of the Russian Federation on issues under joint jurisdiction of the Russian Federation and the subjects of the Russian Federation, the subjects of the Russian Federation and "it is inherent wholesomeness of Republic of Tatarstan ".

\subsection{Characteristics of the subjects of the federation}

The republics of the Russian Federation adopted their own laws on symbols (for example, Law of Republic of Bashkortostan dated 06.07.1999 N10-g (amended on 30.04.2010) "On state symbols of Republic of Bashkortostan ", Law of Republic of Mari El dated 30.11.2006 N 68-g (amended on 08.06.2011) "On State Emblem of Republic of Mari El and State Flag of Republic of Mari El").Similar laws have been adopted and enforced in Tatarstan, Kalmykia, Chuvash Republic and other subjects of the Federation. However, the regional law-makers do not take into account the fact that the symbols of the subjects of the Federation are not emblems of statehood and are not identical to state emblems. They should be named official but not the state symbols of the subjects of the Russian Federation.

On December 19, 2012 a new Russia's National Policy Strategy through to 2025 was approved by RF President's Executive Order. It replaced the Concept of the same name of 1996 which was in force in the territory of the country for sixteen years.

Adoption of the Strategy provides evidence of strengthening of the state constituent in the sphere of regulation of interethnic relations. The Strategy is a current political and legal document taking into account globalization aspects as well as economic, migrational, socio-cultural and demographic processes on the territory of the Russian Federation. The document was adopted in the framework of the state activities on strategic planning and has comprehensive inter-branch nature.

Nevertheless, this document cannot be considered perfect. Specifically, not all the bodies of state power and government officials, that are responsible for Russian state national policy implementation, are noted in it. In addition, forms and methods of interaction between the bodies of state power, local self-government and civil society institutions in the sphere are not made clear. Moreover, the section defining the criteria of implementation effectiveness of the National Policy Strategy as well as the section enabling to identify the main characteristics of the interethnic relations state, namely the interethnic tension level in the country etc. , by special indicators are not included in the document (Zametina, 2013).

The problem is that the legal acts of the subjects of the Federation in the sphere of national relations regulation, that are intended to develop and specify the federal Strategy, are rather inconsistent. In some subjects of the Russian Federation there are documents adopted in between 1995 and 2000 that are still in force now (for example, Udmurtian Republic, Sverdlovsk Region). In other ones there are Implementation Plans and State Programs on implementation of the National Policy Strategy through to 2025that are being adopted (Altai, Chuvash Republic, Republic of Daghestan, Kabardino-Balkarian Republic). Yet, the forms of participation of the bodies of state power of the subjects of the Russian Federation in forming legal, organizational and socio-economic foundation of the national relations at the federal level are not always determined.

Special consideration should be given to youth policy that forms the basis for modernization of different public spheres affecting the formation of the common national idea. Our research conducted in 2012-2013 enabled to reveal a number of significant trends and determinants of youth social development. On the basis of them a conclusion about the shift of its development vector can be made. The process of preferential stagnation of the development indicators, that was characteristic of the period of total uncertainty in the 1990s, started to change its orientation towards positive trends. It led to the increase of the level of income in most young people; a visible tendency towards stabilization of youth employment in the main spheres of production; a positive shift of their orientations from childless families to ones with dependent children; growth of appreciation of education and professional qualification among them; youth support of the current policy and growth of confidence to the federal bodies of power; changing of the emotional state of youth, gradual substitution of fear for feeling of hope and confidence; overcoming a risk escalation peak in the social development, in the well-defined tendency of its localization; efficiency of self-regulation processes and expansion of self-organization in their environment.

\section{Conclusion}

In our opinion, formation of the Russian nation as a single historical community has not finished yet. The term "Russian nation" in that case is used in the ethatique meaning , not in the ethnic one. The Russian nation should not be considered as a conglomerate, mechanically unified community of particular ethnos living in the territory of the Russian Federation. 
This is the single socio-cultural formation based on the interethnic interaction and established in consequence of the long historical development within the boundaries of the Russian state. It is the reasonable national policy oriented to the interethnic integration and general civil consolidation of some certain representatives of the ethnic communities that enables to ensure their well-being and development. Humanistic ideology, nurturing of respect to the Constitution of the RF and laws, consistent implementation of the democratic values and institutions, formation of the affirmations of the tolerant consciousness will contribute to strengthening of the unity of the Russian people and state and creating common communicative environment .

Differentiation of the institution of the Human Rights Commissioner of Russia, specifically, establishment of job titles such as Children's Rights Ombudsman, Business Ombudsman, actualizes the issue about further empowerment of establishing the corresponding human rights bodies. The point at issue is that a new job title of the Peoples' Rights Ombudsman in the Russian Federation should be established.

Development of this institution at the regional level requires adoption of Law "On the Peoples' Rights Ombudsman in the Russian Federation" at the federal level or , at least, , actualizes the issue about the revision of Art.5 of the Federal Constitutional Law of February 26, 1997 "On the Human Rights Ombudsman in the Russian Federation".

Incorporation of a new mechanism , the Peoples' Rights Ombudsman, into the system of the bodies of state power and officials will promote protection and restoration of the peoples' rights in the sphere of their national cultural development; guarantee of equality and self-determination of the peoples; resolution of the "interests conflicts" of state, business and ethnos; prevention of the interethnic conflicts; legal enlightenment and legal culture awareness raising among citizens and officials.

Interethnic relations affect the interests of individuals as well as the Russian society and state in general. Effective national policy is one of the fundamental elements of national security of the Russian Federation. Interethnic conflicts and ethno separatism are able to undermine the foundation of the constitutional system, lead to the massive violations of individual rights and institutions of the civil society.

The research confirmed that objective alterations in the society play a core role in the changes in the social status and motivational sphere of youth awareness. The shift from uncertainty to sustainability is related to the resolution of some contradictions and at the same time creation of the new ones. In terms of youth their nature is rather formal and is determined by more general social determinants while the specific manifestations among young people often become unpredictable and spontaneous in nature. As a result, it becomes necessary to monitor the changes in the youth sphere on the regular basis.

1. During the transition period there have been contradictions between different components of the social status in young people, prolongation of social youth marginalization caused by external factors in institutional nature. These latter largely are survivals of the uncertainty and instability period in the society.

2. Needy youth rates have remained constantly high and even there has been an upward trend in the sphere. Problem solving is closely connected with the programs on advance in living standards of the population in general. In this regard some provisional measures are necessary to introduce. Income-earning youth support should be provided by a large range of measures for youth empowerment of realization of personal potential at work as well as by advance in their social and legal protection level. There are good reasons to link supplementary students material assistance with greater education accessibility. Young families material assistance should be provided ,most significantly, by solving their housing problems.

3. The percentage of idle youth has continued to be high . This category includes the unemployed and those who do not work or study. What is more, most of them do not have any education background or professional qualification. Accounting for it they refer to their unwillingness to work for peanuts. Although these forms of the idle category are clearly different, it is evident that their consequences for young people are equally dangerous. Hence, there should be particular employment programs for these youth categories that took into account the specific nature of different idle category motivations.

4. It seems likely that clear redistribution of youth employment throughout the production spheres (its percentage decrease in the material production and increase in the distribution sphere and intellectual production ) is linked to differential share of the private sector in these spheres and different payment for labor. In terms of economy and social field, unregulated labor outflows from the material production sphere can hardly be justified. Unless the necessary complex measures, mostly economic ones in nature, to regulate this process purposefully are not adopted, reproduction of the state industrial potential can be put in jeopardy.

5. Appeal of agricultural production for labor youth has not increased due to the extant programs in the framework of the corresponding national project. Youth outflows have become significantly active in this sphere for the last few years. It seems to be necessary to work out supplementary measures developed to 
increase youth involvement in developing agribusiness. The corresponding labor ethics has not been formed in the consciousness of young people since the market relations transition period. It was finally evident that in this issue spontaneous market self-regulation proved useless. It is impossible to make a breakthrough to sustainability in the country without extensive public discussion on the issue accompanied by economic and social measures.

The main conclusion to be drawn from the research is that the Constitution of the RF enshrines the rule of the human rights priority ideology as one understands them today. It is impossible to return to the old dogmas during the process of the emergence of a new federative state. A new national integrating idea is necessary. It should be based on democracy, citizenship, patriotism, interethnic peace and the unity of the multiethnic people.

Reforming processes within the Federation, changing geopolitical situation and the measures for state management improvement taken by the government require farther development of legal regulation in the sphere of national relations in the Russian Federation.

\section{Recommendations}

Materials articles of value to government officials, young scientists who are developing documents and laws on youth.

\section{References}

Avakiyan, S.A. (1997). The Constitution of Russia: Nature, evolution, modernity. Moscow, p. 15.

Abdulatipov, R.G. (2000). National issue and form of government in Russia. Moscow. p.379.

Alekseyev, S.V., Kalamov, V. A., Chernenko, A.G. (1998) . Ideological orientation of Russia. In R. V. from Stepashin (ed.), Fundamentals of the new All-Russian national ideology (1, p.27). Moscow.

Barinov, V.V. (2001). Constitutional legal awareness in the Russian Federation. Dissertation Abstract, 15. Rostov-na-Donu.

Dzapsha, F. Z. (1999). Federalism: Modern theory and political experience. V.M. Dolgov (ed.). (p. 184).Saratov.

Zorin, V. Y. , Khabriyeva, T. Y. (2003). State National Policy of the Russian Federation: Problems of implementation and improvement. Journal of Russian Law, 8.

Zametina, T. V. (2013). The State National Policy Strategy of the Russian Federation: Searches of new approaches. Vestnik of Saratov State Academy of Law,4 (93),246-248.

Kokotov, A.N. (1999). Russian nation and Russian statehood. Yekaterinburg.

Kryazhkov, V.A. (2010). Indigenous minorities of the North in the Russian law. Moscow.

Kovalenko, V. I., Goloshumov, Y. V. (1998). National idea as a scientific issue of modern Russian political science. Vestnik of MSU, 12,N 4, p. 14.

Kozlov A.D. (ed.) Constitutional Law: A textbook for higher education institutions.(1996). Moscow. p. 31.

Constitution of the Russian Federation: Problem Comment (1997). V.A.Chetvernin. (ed.). Moscow. p. 69.

Morozova, L. A. (1995). National aspects of the Russian statehood development. Gosudarstvo i pravo, 12.

Mamonov, V.V. (2002).V.T. Kabyshev.(ed.). Constitutional fundamentals of national security. Saratov, p. 133.

Markedonov, S. (2004). Apology of the Russian idea, or how we can preserve Russia. Thesis on the Russian national policy. Moscow, p. 6.

Pevcova E.A. Pravovoe vospitanie i formirovanie pravosoznanija v Rossii// Zhurnal Rossijskogo prava. 2003. № 10.

Pevcova E.A. i dr. Pravovye i social'nye problemy rossijskoj molodezhi// Pravo i obrazovanie. 2008. № 10. S. 90-109

Pevcova E.A. Rol' institutov grazhdanskogo obshhestva v obespechenii pravovoj zashhity detej i molodezhi. // Fundamental'nye i prikladnye issledovanija kooperativnogo sektora jekonomiki. 2014. № 4 . S. 74-79

Pevcova E.A. Pravovoe povedenie i pravovaja aktivnost' lichnosti. // Fundamental'nye i prikladnye issledovanija kooperativnogo sektora jekonomiki. 2014. № 5 . S. 93-98Tishkov, V. A. (1995, January, 30). Russia as a multiethnic community and prospects of interethnic consent: Informational analytical note. Federation Council, Federation Affairs, Federal Agreement and Regional Policy Committee. Moscow, pp. 7-14.

Arzamasov Ju.G., Pevcova E.A. Novoe "ukaznoe" normotvorchestvo: obshhaja harakteristika rezul'tatov; tendencii razvitija //Gosudarstvo i pravo. 2010. № 1. S. 12-20.

Pevcova E.A., Chuprov V.I. Zubok Ju.A. Pravovye i social'nye problemy rossijskoj molodezhi //Pravo i obrazovanie. 2008. № 10. S. 90109.

Pevcova E.A. Juridicheskoe obrazovanie: formirovanie pravovoj kul'tury obshhestva //Fundamental'nye i prikladnye issledovanija kooperativnogo sektora jekonomiki. 2012. № 5. S. 119-122.

Khabibulin, A. G., Rakhimov, R.A.(1993). State ideology :revisiting eligibility for the category. Gosudarstvo i pravo, 3, p.13.

Habermas,J. (1996). Democracy. Mind. Ethics. Moscow, p. 60.

Tsybulevskaya, O. I. (2001). Proceedings from ISPC '01: On moral aspect of the implementation of the principle "Unity of rights and responsibilities". Saratov. p. 153.

Avakiyan, S.A. (2000, April 27-28). Proceedings from MSC : National Issue and State Building: Problems of Russia and Experience of Foreign Countries. Moscow. 